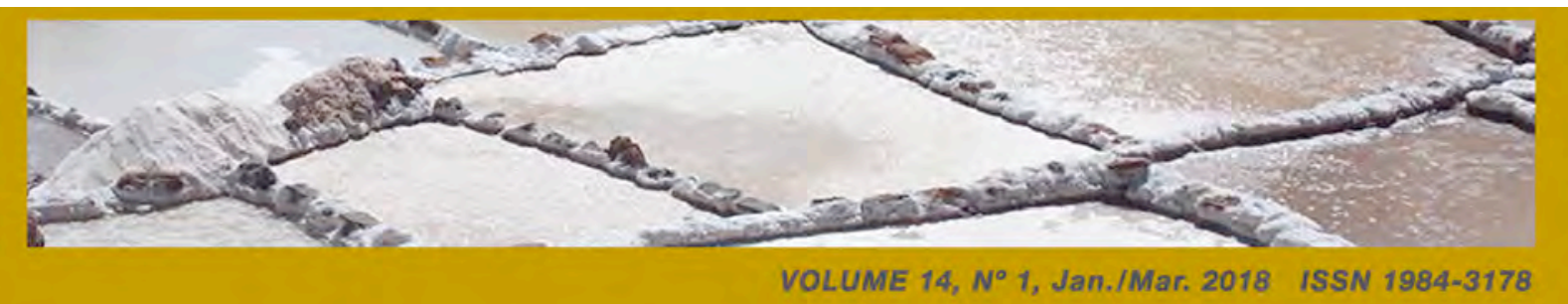

\title{
A INFLUÊNCIA DO PROJETO JARDIM DE GENTE NA REINVENÇÃO DO COTIDIANO: UM ESTUDO COM OS JOVENS DO BAIRRO BOM JARDIM
}

\section{THE INFLUENCE OF THE "JARDIM DE GENTE" PROJECT FOR EVERYDAY LIFE REINVENTION: A STUDY WITH YOUNG PEOPLE OF NEIGHBORHOOD "BOM JARDIM"}

DOI: http://dx.doi.org/10.5965/1984317814012018129

Gabriel Nunes Lopes Ferreira e Marco Antonio Toledo Nascimento - Universidade Federal do

Ceará

\begin{abstract}
RESUMO
O presente trabalho aborda a educação musical em espaços não escolares de ensino e como esses espaços contribuem para a educação musical na periferia de Fortaleza. A pesquisa tem como objetivo compreender, sob a perspectiva dos estudantes, a importância dos cursos de Música realizados pelo Projeto Jardim de Gente (bairro Bom Jardim - Fortaleza/ Ceará/ Brasil). Como abordagem metodológica, foi realizado um estudo de caso no curso de Prática de Conjunto. As fontes de evidência utilizadas foram os planos de aula do curso, o Projeto Político Pedagógico do Projeto e também as entrevistas com dez estudantes que participaram do curso no período de 2010 a 2013. Assim, o curso de Prática de Conjunto assume o papel de um espaço de mudanças de percepções com relação à prática musical e também com relação às atividades cotidianas dos estudantes. De acordo com os resultados, o Projeto surge como um espaço de democratização do saber musical, reinventando o cotidiano de seus frequentadores.
\end{abstract}

Palavras-chave: Educação Musical. Educação Não Formal. Cotidiano.

\begin{abstract}
This paper discusses music education at non-school spaces of education and how these spaces contribute to the musical education on the outskirts of Fortaleza. The project aims to understand the importance of music courses held by the Project "Jardim de Gente" (Garden of People - Fortaleza/ Ceará/ Brazil) through the students' perspective. As a methodological approach, a case study in the course of Joint Practice was made. Ten students who participated in the course in the period 2010 to 2013 were chosen and interviewed. In addition to this, course planning and the Pedagogical Political Project of "Jardim de Gente" were used as sources of evidence. Thus, the Joint Practice course emerges as a space of transformation concerning musical practical perceptions and also in relation to daily students activities. According to the results, the project appears as a tool to the democratization of musical knowledge, reinventing the everyday life of its attendees.
\end{abstract}

Keywords: Music Education. Non-formal Education. Everyday life. 


\section{INTRODUÇÃO}

No Brasil, a educação musical em espaços não escolares vem crescendo bastante dentro de áreas consideradas periféricas das grandes cidades brasileiras. Em Fortaleza, isso também acontece em bairros como o Grande Bom Jardim, que "reflete uma cidade desigual, incidindo os seus reveses na parcela da população mais vulnerável, em razão do seu particular processo de desenvolvimento, principalmente as crianças, adolescentes e jovens" (HONÓRIO, 2014, p.37).

Depois de conhecer o bairro em 2010, e desde então lecionando em espaços não escolares da região, conheci melhor as atividades musicais do Grande Bom Jardim, mais especificamente os cursos do Projeto Jardim de Gente, que funcionam nas instalações do Centro Cultural Bom Jardim (CCBJ) ${ }^{1}$. A partir destas vivências, senti a necessidade de compreender minha função enquanto educador daquele espaço e de que maneira as aulas e o Projeto movimentavam e influenciavam a vida musical dos frequentadores e moradores do bairro. Essa necessidade se amplia para também mostrar o outro lado do Grande Bom Jardim, que sempre ficou escondido por causa da ênfase nos casos de violência frequentemente divulgados nos grandes veículos de comunicação de Fortaleza.

Para notarmos a presença da Música em diferentes espaços educacionais fora do ambiente escolar, nos baseamos em diversos autores, como: Hikiji (2006), Fucci Amato (2009), Kleber, Cacione e Erthal (2010), Maciel (2010), Oliveira (2010), Oba e Louro (2010), Eckert e Louro (2010), Weiland (2010), Gaulke e Louro (2010), Weiland e Fermino (2012), Penna, Barros e Mello (2012), Stravacas (2013) e Kleber (2006; 2010; 2014).

A prática e o ensino de Música têm crescido consideravelmente nesses espaços e, por conseguinte, as pesquisas sobre essa temática. Essas demonstram que esses espaços atuam de maneira complementar à instituição escolar, tendo em vista que, na escola, o ensino de Música não agrega de maneira sistematizada todos os estudantes (ALMEIDA et al, 2015).

\footnotetext{
${ }^{1}$ Equipamento do Governo do Estado do Ceará implantado em 2006 e coordenado pelo Instituto de Arte e Cultura do Ceará (IACC).
} 
Assim, torna-se de grande relevância analisar as práticas musicais de espaços não escolares, como as que acontecem no Projeto Jardim de Gente, tendo em vista que essas atuam muitas vezes como o único acesso gratuito à aprendizagem musical, principalmente para população da periferia. Além disso, percebeu-se que vários estudantes estavam investindo nos estudos musicais diários e/ou dando continuidade às práticas musicais como profissionais $^{2}$.

Nessa perspectiva, o problema investigado na pesquisa foi: qual o papel do curso de Prática de Conjunto do Projeto Jardim de Gente na mudança do cotidiano de seus estudantes? Buscou-se, assim, analisar o papel do ensino de música do curso de Prática de Conjunto do Projeto Jardim de Gente na mudança do cotidiano de seus estudantes durante o período de 2010 a 2013. A pesquisa baseou-se na metodologia qualitativa, que busca o significado das práticas dos indivíduos e o sentido que cada um dá a essas. Como estratégia qualitativa utilizou-se o Estudo de Caso.

O referencial teórico principal da pesquisa está baseado em Bourdieu (1998; 2013), com seus estudos sobre jogos de poder e classes sociais; Certeau (2013), com sua pesquisa sobre cotidiano e Koellreutter ${ }^{3}$ (1997) com sua proposta de Educação Musical.

Para uma melhor compreensão da pesquisa, o texto a seguir está divido em duas partes: a primeira discute os espaços de educação além da instituição escolar, as atividades do Projeto Jardim de Gente e o referencial teórico utilizado na pesquisa; e a segunda explicita como se deram os procedimentos metodológicos do trabalho e as considerações finais ${ }^{4}$.

\footnotetext{
${ }^{2}$ Identificamos egressos lecionando, tocando ou mesmo dando continuidade aos estudos em cursos de graduação ou técnico na área de Música da cidade de Fortaleza.

${ }^{3}$ A pesquisa de Brito (2011) sobre os ensinamentos de Koellreutter também será utilizada nesse estudo.

${ }^{4}$ Os dados obtidos serão apresentados no decorrer do texto.
} 


\section{O ENSINO DE MÚSICA ALÉM DA INSTITUIÇÃO ESCOLAR E O PROJETO JARDIM DE GENTE}

O ensino de música no Brasil vem se desenvolvendo em diversos âmbitos. Apesar disso, mesmo com as grandes mudanças sócio-políticas, a prática musical ainda continua, em alguns contextos, com os mesmos preceitos tradicionais de outros tempos, utilizando um repertório europeu e descaracterizando as vivências e práticas musicais dos estudantes.

Entre os diversos espaços com ensino de Música, sejam eles dentro de ambientes formais ou não, percebemos em Fortaleza, mais especificamente nos bairros mais periféricos da cidade, diversas práticas musicais fora da instituição escolar. Elas podem se apresentar através de projetos sociais, espaços religiosos, ou ainda através do conhecimento compartilhado entre as pessoas, tendo em vista que "o saber pedagógico-musical emerge das interações e práticas sociais inerentes aos mais diferentes contextos da sociedade contemporânea" (KLEBER, 2006, p.02). Se essas práticas sociais forem deslegitimadas, acabam promovendo a exclusão social de seus participantes.

Essas práticas crescem a cada dia, seja dentro da comunidade em que estão inseridas como também através das pesquisas no campo acadêmico, que sente a necessidade de refletir e compreender mais sobre essas atividades musicais fora do ambiente escolar. Esses espaços atuam diminuindo as lacunas do conhecimento musical à comunidade, democratizando o saber musical.

Percebemos que a Música, nesses espaços formais de ensino, está presente através de projetos e práticas esporádicas, sem continuidade e avaliação dos resultados favorecendo a criação de espaços educacionais alternativos. Espaços esses que acabam trabalhando de maneira complementar a instituição escolar, muitas vezes oferecendo o que falta na escola, como a Arte por exemplo. Geralmente são espaços oriundos de movimentos populares organizados e que procuram na prática musical uma alternativa para retirar jovens da exclusão social tendo como parceiras, diversos outros espaços como a própria instituição escolar e também as universidades (FERREIRA, 2014, p. 03). 
Para Kleber (2010), esses espaços promovem a formação humana e o contexto onde estão inseridos, direcionando suas potencialidades com objetivos práticos (fazer e performance musical). Tratam-se de espaços onde ocorre a mudança dos sujeitos participantes, uma nova prática democrática dentro do cotidiano das pessoas envolvidas.

Gaulke e Louro (2010), ao relatarem suas experiências nessas instituições, afirmam que esses projetos também objetivam a formação do ser humano, melhorando sua qualidade de vida e facilitando sua convivência em sociedade (OLIVEIRA, 2010; OBA E LOURO 2010; STRAVACAS, 2013).

Em Fortaleza, percebemos um crescimento dessas instituições principalmente na periferia da cidade. Podemos citar como exemplo:

a) O CCBJ que, além de cursos oferecidos pelo Projeto Jardim de Gente, disponibiliza para a comunidade do Grande Bom Jardim uma diversidade de atividades culturais e;

b) os Centros Urbanos de Cultura, Arte, Ciência e Esporte (CUCA's), que possuem atualmente três "sedes" (nos bairros da Barra do Ceará, Jangurussu e Mondubim).

A pesquisa teve como foco inicial o Projeto Jardim de Gente, que tem no CCBJ o espaço principal de atuação, mas que faz parceria com outras instituições do bairro, expandindo os cursos para toda a comunidade do Grande Bom Jardim ${ }^{5}$.

O CCBJ surgiu no Bom Jardim no final de 2006, instigado por discussões entre o Governo do Estado do Ceará e os moradores do bairro, que começaram a questionar a centralização das ações culturais de Fortaleza nas redondezas do Centro Dragão do Mar de Arte e Cultura (localizado em um bairro de classe média/alta da cidade) e a consequente ausência nos arredores do Bom Jardim.

As ações culturais do CCBJ estão divididas em quatro instâncias:

1. Serviços de atendimento ao público de um modo geral (e aqui são incluídos artistas e produtores culturais, através da disponibilização dos espaços do Centro Cultural);

\footnotetext{
${ }^{5} \mathrm{O}$ Grande Bom Jardim se divide em cinco outros bairros menores: Bom Jardim, Canindezinho, Granja Lisboa, Granja Portugal e Siqueira.
} 
2. Programação cultural através dos shows e espetáculos culturais dos artistas do bairro e de outras regiões da cidade;

3. Exposições e intervenções;

4. Formação em arte e cultura;

A formação em arte e cultura é direcionada pelos cursos do Projeto Jardim de Gente, que teve início em 2007. O projeto, apesar de também ser gerenciado pelo Instituto de Arte e Cultura do Ceará (IACC), tem recurso advindo do Fundo de combate à pobreza (FECOP) que, instituído pela Lei complementar $n^{\circ} 37 / 2003$, tem como objetivo combater a pobreza através de uma formação artística e cultural.

Além disso, em 2012 os cursos tiveram como foco a profissionalização dos estudantes, buscando resultados mais objetivos no combate à pobreza (HONÓRIO, 2014). Surge assim uma dualidade nas práticas do projeto: por um lado, há o foco na profissionalização e em melhores resultados para o relatório final do projeto e, em contrapartida, "a intenção de proporcionar aos alunos a vivência com as linguagens artísticas e um aprofundamento do conhecimento cultural" (HONÓRIO, 2014, p. 56).

O projeto geralmente utiliza a maior parte da carga horária para os cursos de Música $^{6}$. Dentre eles, a pesquisa teve como foco principal o curso de Prática de Conjunto por ser aquele que apontou o maior direcionamento de estudantes para a profissionalização em Música (mesmo direcionando as atividades para a vivência e aprofundamento cultural).

O curso de Prática de Conjunto surgiu em $2009^{7}$ por iniciativa dos próprios estudantes, pois esses mostraram interesse em realizar uma atividade musical mais ampla e que pudesse congregar as diversas práticas já existentes no espaço. Atendendo a essa demanda, foi estruturado um curso com a proposta de formar um grupo musical que trabalhasse em uma perspectiva integradora, tanto pelos diversos instrumentos musicais, como pelas vivências plurais e anteriores dos estudantes participantes. Com exceção da

\footnotetext{
${ }^{6}$ Violão Iniciante e Avançado, Prática de Conjunto, Percussão (construção de instrumento de percussão), Teclado, Coral (Infantil e Terceira Idade) e Técnica Vocal.

${ }^{7}$ Assumi o curso no ano de 2010 até 2012. A partir de 2012 o curso contava com dois professores, mas ambos dentro do mesmo planejamento.
} 


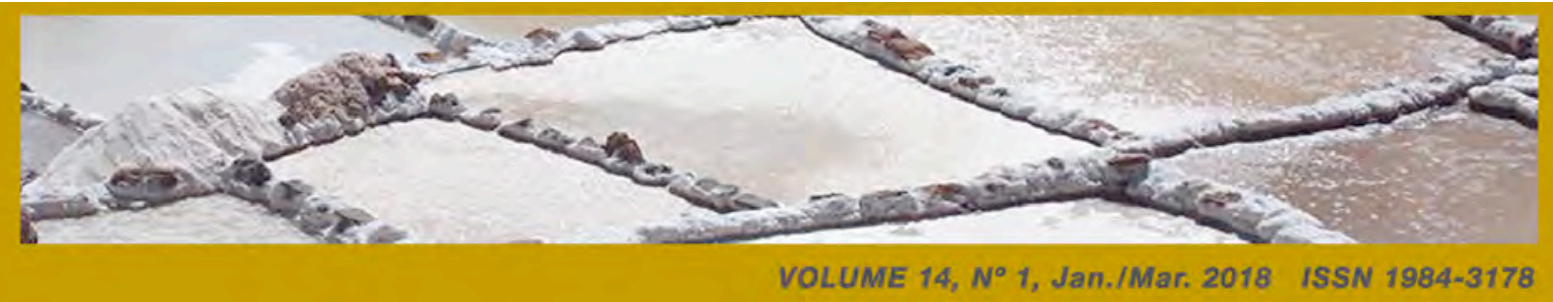

bateria, os alunos precisavam ter e levar os respectivos instrumentos durante as aulas e apresentações.

O repertório era preparado durante as aulas, com a participação de todos os estudantes, e contava geralmente com artistas brasileiros populares (Tim Maia, Jorge Ben Jor, Raul Seixas, Lenine, Paula Fernandes, Marina Lima entre outros), alguns grupos da música católica e gospel (Rosa de Saron, Oficina G3 e Toque no Altar) e também composições dos próprios estudantes ${ }^{8}$.

O curso se diferenciava das outras atividades do projeto pela junção de diversos instrumentos nas aulas. $\mathrm{O}$ foco então era a construção de um repertório através do trabalho em grupo. Os instrumentos mais utilizados eram o violão, a guitarra e a voz, mas os guitarristas poderiam tocar percussão em algumas músicas ou ir para o contrabaixo em outras, por exemplo. O único pré-requisito para entrada no curso era ter seu instrumento e geralmente eram disponibilizadas de 15 a 20 vagas.

Além disso, o Projeto não restringe suas atividades a nenhum perfil de idade. Isso acontece apenas por escolha do professor que tem autonomia para definir a faixa etária dos estudantes de seu curso. Em 2013, por exemplo, a maior quantidade de alunos, segundo o relatório final do Projeto, estava entre os 16 e 29 anos e em segundo lugar, 30 anos em diante. O curso de Prática de Conjunto nunca definiu a idade dos participantes.

Os preceitos filosóficos que embasaram as propostas didáticas do curso de Prática de Conjunto seguiram a proposta de Educação Musical de Koellreuter, que será exposta na próxima parte desse texto, juntamente com a análise de como essas práticas musicais se apresentaram aos estudantes.

\section{DAS PRÁTICAS MUSICAIS NÃO ESCOLARES ÀS TÁTICAS DOS CONSUMIDORES}

\footnotetext{
${ }^{8}$ Uma dessas composições pode ser ouvida através do seguinte link:< https://goo.gl/vgaM6V >. A Música foi gravada pelos estudantes do grupo em 2012.
} 
As propostas formativas musicais dentro dos cursos de Música do Projeto Jardim de Gente perpassavam vários objetivos, como visto anteriormente. Após uma análise das práticas dos cursos e das entrevistas realizadas com os estudantes, percebemos uma grande ligação dessas atividades com as propostas pedagógicas e formativas do educador musical Koellreutter.

Para ele, a linguagem musical é um "meio de ampliação da percepção e da consciência, que contribui para a superação de preconceitos e pensamentos dualistas decorrentes do racionalismo, do mecanicismo e do positivismo" (BRITO, 2011, p.28). Indo mais além, Koellreutter afirma que a Música é um meio para a expansão da consciência e para a modificação do homem e do contexto social que o cerca.

O curso de Prática de Conjunto e o próprio Projeto Jardim de Gente não se preocupam apenas com a formação musical em sentido estrito, mas também com esse contexto social do bairro, contribuindo de maneira significativa na formação humana de seus estudantes. Percebemos esses aspectos na análise das entrevistas de dois alunos (Eliana e Leandro), que serão representados aqui pelo relato de um deles:

[...] quando eu vou tocar em outros lugares que eu não vejo que é justamente esse lance de se escutar, de se respeitar, ter essa admiração pelo que o outro tá fazendo, e... esse trabalho de equipe e você ir construindo... pega uma música e vai construindo ... de pouquinho em pouquinho e vai fazendo essa colcha de retalhos assim, aos poucos... e... isso é puramente trabalho de equipe que você vai levar pras outras áreas da sua vida (LEANDRO).

Percebemos neste relato uma educação musical significativa, que tem como função não apenas o desenvolvimento de musicistas e virtuoses, mas também a missão de "desenvolver a personalidade do jovem como um todo [...] o humano, meus amigos, como objetivo da educação musical” (KOELLREUTTER, 1998, p.39-45 apud BRITO, 2011, p.43-44).

Dentro dessa perspectiva de formação humana citada por Koellreutter, a estudante Samila aponta alguns elementos importantes em sua trajetória formativa musical, ao discursar sobre a importância do Projeto e do curso de Prática de Conjunto. 
É muito importante, porque lá no Centro Cultural, tanto as pessoas, quem administra e os professores e até mesmo os alunos também, a gente aprende muito pela experiência de vida de cada um também. Pelo Bom Jardim ser um bairro de periferia e tudo, a gente escuta muita coisa e a gente aprende muito. Ajuda na nossa... no nosso desenvolvimento como pessoa, como cidadão. Também a arte e todas essas coisas que são oferecidas pelo Projeto, elas formam a gente tanto aspectos profissionais... tem muita gente que aprendeu coisas no Jardim de Gente, fez cursos no Jardim de Gente e trabalha com isso atualmente e... também tem pessoas que usam, mesmo que não trabalham na área, mas que usam, assim como eu, usam o que aprenderam no Jardim de Gente pro seu trabalho, de vez em quando precisa de alguma coisa. É muito importante porque soma. Soma... tudo que você faz... tudo que eu fiz lá no Centro Cultural pelo Jardim de Gente, somou e a prática de conjunto é... muito mais, porque é hoje o que eu vivo lá na igreja. Que... não é a mesma coisa, mas é a mesma ideia e são coisas que me ensinaram e somaram pra tudo que eu sei hoje e me ajudaram também a aprender, a aprender essas coisas da Música (SAMILA).

Apesar disso, "a educação musical continua a ser, no Brasil, o mais sério problema do terreno da música. [...] Os pais e educadores desconhecem ainda o inestimável valor educacional e socializante das disciplinas musicais, como a música de conjunto [...]" (KOELLREUTTER, 1997, p.109).

Vinte anos após esta afirmação, mesmo com todas as inovações pedagógicas e metodológicas, percebemos ainda, em muitas instituições, um ensino de Música pensado como prática segregadora, compartilhada com uma minoria e não como uma prática que vai além da formação de virtuoses.

A partir dessa explicação, compreendemos como o Projeto Jardim de Gente dialoga, mesmo que de maneira não intencional, com a proposta formativa musical de Koellreutter, que é uma das características de espaços formativos não escolares em regiões com carências estruturais e educacionais.

Nesse sentido, nos questionamos até que ponto o projeto e seus cursos, mais especificamente o de Prática de Conjunto, dialogavam com o cotidiano dos estudantes e em que esferas formativas estavam atuando. 
Para isso, é importante compreender os jogos de poder que se fazem presentes dentro de nossa sociedade e como o cotidiano desses jovens é influenciado dentro desses jogos sociais.

Assim, a partir da vivência em um sistema com marcas distintivas que "desenha o sistema de estilos de vida" (BOURDIEU, 2013, p.112), denominado pelo mesmo autor de sistema simbólico, percebemos que o campo musical também surge como uma prática de distinção, tendo em vista que as possibilidades de aprendizagem para uma parcela da população, em detrimento da outra, são bem diferenciadas. Isso ocorre tanto na oferta dos espaços, como também com o tipo de formação e os objetivos dessas instituições.

Certeau (2013) também discute acerca desse sistema simbólico, mas utilizando o termo estratégia, que dialoga com Bourdieu (2013):

Chamo de "estratégia" o cálculo das relações de forças que torna possível a partir do momento em que um sujeito de querer e poder é isolável de um "ambiente". Ela postula um lugar capaz de ser circunscrito como um próprio e portanto capaz de servir de base a uma gestão de suas relações com uma exterioridade distinta. A nacionalidade política, econômica ou científica foi construída segundo esse modelo estratégico (CERTEAU, 2013, p. 45).

Além disso, Certeau (2013) utiliza também o conceito de táticas que, ao contrário das estratégias, não possuem autonomia como "um próprio". São ações, portanto, imprevisíveis, realizadas pelos consumidores com o objetivo de fugir do sistema vigente. São pequenas vitórias diante dos produtores no cotidiano da cultura ordinária, espaço principal das práticas dos consumidores ou "não produtores".

Percebemos que essas táticas dentro do bairro Bom Jardim têm a colaboração das atividades do Projeto Jardim de Gente. O Projeto acaba introduzindo nos consumidores “uma 'arte’ que não é [de] passividade” (CERTEAU, 2013, p.49).

Nessa perspectiva, esses conceitos surgem para compreender e explicar as práticas musicais do Projeto Jardim de Gente, dialogando com o cotidiano de seus frequentadores. Tendo em vista que, indo além da passividade e das categorias definidas por Heller (2008), 
surgem "maneiras de fazer" e uma "antidisciplina" (CERTEAU, 2013, p.41) que acabam fugindo da reprodução imposta pelo sistema simbólico.

Não há vida cotidiana sem espontaneidade, pragmatismo, economicismo, antologia, precedentes, juízo provisório, ultrageneralização, mimese e entonação. Mas as formas necessárias da estrutura e do pensamento da vida cotidiana não devem se cristalizar em absolutos, mas têm, de deixar ao indivíduo uma margem de movimento e possibilidades de explicitação. (HELLER, 2008, p. 56).

O que está por trás, por exemplo, de um estudante que, depois do ensino técnico integrado (no ensino médio), e que tem naturalizado nos discursos ao seu redor a prática profissionalizante, busca na prática musical um futuro profissional?

Certeau (2013) responde essa pergunta quando afirma que:

A presença e a circulação de uma representação (ensinada como o código da promoção socioeconômica por pregadores, por educadores ou por vulgarizadores) não indicam de modo algum o que ela é para seus usuários. É ainda necessário analisar a sua manipulação pelos praticantes que não a fabricam. Só então é que se pode apreciar a diferença ou a semelhança entre a produção da imagem e a produção secundária que se esconde nos processos de sua utilização (CERTEAU, 2013, p. 39).

A pesquisa busca conhecer justamente esses praticantes (usuários, consumidores ou dominados do Bom Jardim) e suas maneiras de fazer (música), tendo em vista que as práticas musicais mantêm uma relação de reprodução de práticas passadas além da existência, ainda hoje, do mito do dom e do ser talentoso.

Ideias como destino, talento inato, predestinação, ligadas a teorias religiosas e à ideologia veiculada pelos meios de comunicação em massa, contribuem para formar nas pessoas a concepção de que um músico, um pintor, um ator já nasceram para realizar aquela atividade e são pessoas "únicas" e “especiais" (FUCCI AMATO, 2008, p. 81). 


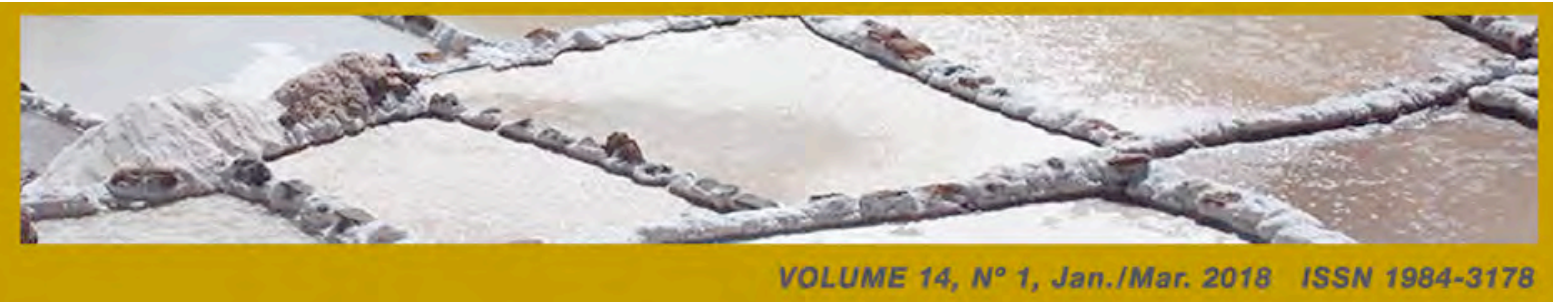

Percebemos, a partir dessa análise, que isso torna a arte de fazer música restrita a uma minoria, geralmente com maior oportunidade e incentivo por parte do meio social em que estão inseridos. Trata-se da "ideologia do dom" (BOURDIEU, 1998, p. 59), ou seja, um meio pelo qual a elite produtora (de disciplina) justifica as diferenças econômicas, logrando êxito em suas práticas e disseminando a naturalização da falta de dom dos consumidores.

O que acontece realmente é a formação musical através, inicialmente, da família que transmite certos bens culturais a seus filhos. Esses conseguem e mantém certa posição social, graças ao status adquirido anteriormente, e consequentemente uma conservação das desigualdades sociais e culturais.

Mas existe a possibilidade de mudar essa cotidianidade reprodutivista? Certeau (2013), ao citar o exemplo da arte de conversar, nos responde esse questionamento. O exercício da conversa ordinária é um momento de uma prática transformadora em vários sentidos e que não possui um proprietário individual. "A conversa é um efeito provisório e coletivo de competências na arte de manipular 'lugares-comuns' e jogar com o inevitável dos acontecimentos para torná-los 'habitáveis"” (CERTEAU, 2013, p. 49).

Seguimos assim, colaboradores de Certeau, buscando "que procedimentos populares [...] jogam com os mecanismos da disciplina e não se conformam com ela a não ser para alterá-los" (CERTEAU, 2013, p. 40). Para dar voz às pessoas ordinárias e compreender melhor suas táticas na arte de fazer Música, será explicitado a seguir os passos metodológicos da pesquisa para posterior discussão dos dados e conclusão do trabalho.

\section{METODOLOGIA}

Nessa etapa do trabalho, será explicitado o método escolhido para a pesquisa e suas características. Depois de várias leituras acerca de metodologias da pesquisa científica, foi escolhido o método qualitativo para o estudo.

Tendo como base o fenômeno humano-musical no Grande Bom Jardim em Fortaleza, mais especificamente o cotidiano dos frequentadores do Projeto Jardim de Gente, 
a escolha do método qualitativo se justifica porque busca adentrar no universo simbólico dos estudantes e, assim, "compreender os significados que [esses] dão aos seus comportamentos ou as suas vidas" (ANADON, 2005, p.11).

A estratégia qualitativa (CRESWELL, 2010) utilizada foi um Estudo de Caso único incorporado (sendo o curso de Prática de Conjunto o caso original) que aqui seguirá os planos estruturais de Yin (2010). O Estudo de Caso busca compreender um fenômeno em seu contexto real, principalmente quando os limites desse não estão evidentes.

Dentre as diversas fontes de evidências (YIN, 2010) utilizadas na pesquisa, podemos citar: o Projeto Político Pedagógico e as revistas anuais do CCBJ para compreensão acerca da função dos cursos e seu público alvo, e as entrevistas com os estudantes do curso, além do planejamento das aulas.

Dos 36 estudantes que participaram das atividades do curso no período entre 2010 e 2013, foram escolhidos dez alunos para as entrevistas a partir dos seguintes critérios:

1. Cinco estudantes que deram continuidade ao estudo da Música profissionalmente (ou tinham essa pretensão) ${ }^{9}$;

2. Cinco estudantes que não continuaram o trabalho musical desenvolvido e estariam atualmente com outras atividades remuneradas ${ }^{10}$.

As entrevistas em profundidade, que para Yin (2010, p.133) trata-se de "perguntar aos respondentes-chave sobre os fatos de um assunto, [aqui pensado como a importância do curso em suas respectivas formações] assim como suas opiniões sobre os eventos", seguiram um roteiro pré-estabelecido com as seguintes perguntas:

1. Para começar, você poderia se apresentar falando seu nome, sua idade, onde (qual ano escolar?) estuda e qual atividade profissional exerce?

2. Você pode falar um pouco sobre como é morar no Bom Jardim e quais os espaços com ensino de Música você conhece na região?

\footnotetext{
${ }^{9}$ Estudantes: Victor, Salatiel, André, Silvio e Marlon.

${ }^{10}$ Estudantes: Samila, Leandro, Eliana, Beneildo e Mariana.
} 
3. Você teve alguma vivência musical na família? Alguma influência por parte de algum parente para aprender Música?

3.1 Seus pais trabalham com que atividade?

4. Você pode falar um pouco sobre como aconteceu sua iniciação musical, em quais espaços e com quem teve aula? E por que a procura por um curso de música? Apenas hobby ou tinha alguma intenção profissional?

5. Como foi o primeiro contato com o Centro Cultural Bom Jardim e com o Projeto Jardim de Gente? Como conheceu esse espaço? Fez outros cursos além do curso de Prática de Conjunto?

6. Está exercendo alguma atividade musical? Alguma banda, dando aulas particulares?

7. Ainda frequenta o Centro Cultural? Faz algum curso? Fez amigos? Mantém contato com alguém que conheceu no projeto durante os cursos que fez?

8. O que você acha que mudou em você depois que fez o curso? Não apenas musicalmente, mas fique à vontade para falar sobre outros aspectos que ache relevante.

9. Qual a importância que você dá as atividades do Projeto Jardim de Gente e do curso de Prática de Conjunto para sua formação ${ }^{11}$

Todas as entrevistas foram transcritas, e a análise será explicitada na próxima parte do trabalho.

\subsection{Análise e discussão dos resultados}

Após a coleta dos dados, a análise e a interpretação seguiram como protocolo a codificação teórica introduzida por Glaser e Strauss (1967) e aperfeiçoada por Strauss e Corbin (1990). A interpretação dos textos tem como função, além de desenvolver o referencial teórico da pesquisa, contribuir para saber quais dados extras necessitam ser coletados. Por isso, a interpretação inicial dos dados não pode estar desassociada da coleta.

\footnotetext{
${ }^{11}$ Pergunta acrescentada depois do pré-teste.
} 
A análise teve como princípio a redução e categorização do texto original, procedimento esse que foi dividido em três etapas:

1. A codificação aberta surgiu na análise para reduzir fenômenos e dados em conceitos. Trata-se do "processo analítico pelo qual os conceitos são identificados e desenvolvidos em termos de suas propriedades e dimensões" (STRAUSS E CORBIN, 1990, p.74).

2. A codificação axial teve como objetivo aprimorar e expandir as categorias originárias da codificação aberta. Para isso, além das questões explicitadas anteriormente, conta-se com o que Strauss e Corbin (1990) denominam de paradigma da codificação, que está representado na figura abaixo:

Figura 1 - Paradigmas de codificação.

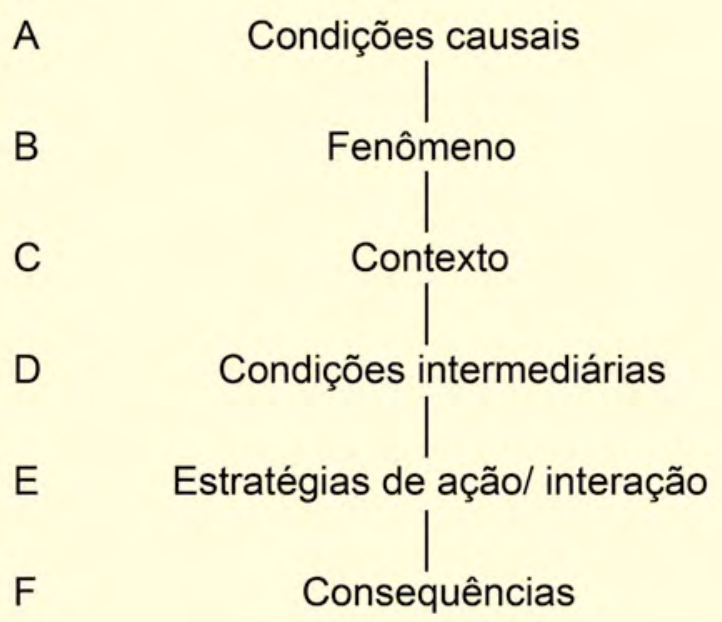

Fonte: Strauss e Corbin (1990, p. 99).

3. A codificação seletiva teve como objetivo desenvolver a categoria principal da pesquisa, podendo assim integrar as outras.

A partir dessas três etapas, chegamos às seguintes categorias: 


\begin{tabular}{|c|c|c|}
\hline \multirow[t]{4}{*}{ Apresentação } & Fenômeno & Contexto \\
\hline & \multirow[t]{3}{*}{ Intenção na prática musical } & $\begin{array}{l}\text { Motivação por parte dos pais à } \\
\text { prática musical }\end{array}$ \\
\hline & & $\begin{array}{c}\text { Onde estudou (Educação } \\
\text { Regular) }\end{array}$ \\
\hline & & $\begin{array}{l}\text { Espaços de aprendizagem } \\
\text { musical na região onde mora }\end{array}$ \\
\hline $\begin{array}{l}\text { Estratégias de ação/ } \\
\text { Interação }\end{array}$ & Causa & Consequência \\
\hline Iniciação Musical & \multirow[t]{4}{*}{$\begin{array}{l}\text { Importância do Projeto e do } \\
\text { Curso de Prática de conjunto }\end{array}$} & \multirow[t]{4}{*}{$\begin{array}{c}\text { Atividades Musicais que está } \\
\text { desenvolvendo }\end{array}$} \\
\hline $\begin{array}{l}\text { Primeiro contato } \\
\text { com o CCBJ }\end{array}$ & & \\
\hline $\begin{array}{l}\text { Início na Prática de } \\
\text { Conjunto }\end{array}$ & & \\
\hline $\begin{array}{l}\text { Permanência no } \\
\text { curso de Prática de } \\
\text { Conjunto }\end{array}$ & & \\
\hline
\end{tabular}

Fonte: Arquivo pessoal.

Percebemos assim que o fenômeno fica bem claro dentro da pesquisa, dialogando com as outras categorias e nos fazendo compreender como os estudantes chegaram até a decisão de trabalhar com Música ou não, além da relação do Projeto nessa escolha que modifica seu cotidiano.

Para compreender essa mudança, é importante analisar o contexto das práticas musicais dos estudantes e como as categorias citadas anteriormente dialogam com o fenômeno principal.

Assim, iniciamos a análise do contexto através da motivação por parte da família para a aprendizagem musical. Seis dos estudantes (André, Mariana, Samila, Silvio, Beneildo e Eliana) foram motivados pela família para a prática musical. Apesar disso, muitas vezes essa motivação não é suficiente para que a aprendizagem e a prática musical se desenvolvam de maneira satisfatória e significativa. Os outros estudantes entrevistados tiveram outras influências, como os amigos, por exemplo. 
Ao analisar as práticas musicais dentro da escola regular (segunda categoria contexto), apenas dois alunos (Marlon e André, respectivamente) tiveram vivência musical nesse espaço - um deles na escola particular (em outro bairro) e o outro em uma escola pública (instituição no Grande Bom Jardim), através de um projeto no contraturno. É importante ressaltar aqui que esses estudantes hoje se encontram trabalhando com música: o primeiro faz o curso de Música da Universidade Federal do Ceará (UFC) e leciona em duas escolas, e o segundo toca em diversos grupos e leciona na igreja.

A partir dessa análise, percebemos em quais espaços a formação musical no bairro acontece, tendo em vista que, quando questionamos os estudantes acerca dos espaços de aprendizagem musical na região, surgem em seus relatos os seguintes locais:

a) Projeto Jardim de Gente;

b) Grupo Brincantes de São Francisco;

c) Igrejas;

d) Residência;

e) Centro de Atenção Integral à Criança e ao Adolescente (CAIC) Alves Carioca (Escola estadual com aulas de instrumentos de cordas friccionadas).

Fica patente que o interesse pela música é proporcional às oportunidades que cada indivíduo tem de ter contato com abordagens mais estruturadas e contínuas com a música. Fica também claro que, uma vez em contato com uma abordagem, ocorre um enriquecimento da capacidade de percepção e de elaboração crítica. A ampliação dos horizontes musicais do indivíduo (seja no âmbito da percepção pessoal, seja no âmbito da riqueza e variedade de repertórios) serve de auxílio para o alargamento dos horizontes de percepção da realidade como um todo (ROBATTO, 2012, p.51).

Nessa perspectiva, percebemos as táticas para que a aprendizagem musical aconteça e que já adentra na categoria das estratégias de ação/ interação dos estudantes entrevistados. Essas táticas agem onde não existe poder e são utilizadas "vigilante as falhas que as conjunturas particulares vão abrindo na vigilância do poder proprietário. Aí vai 


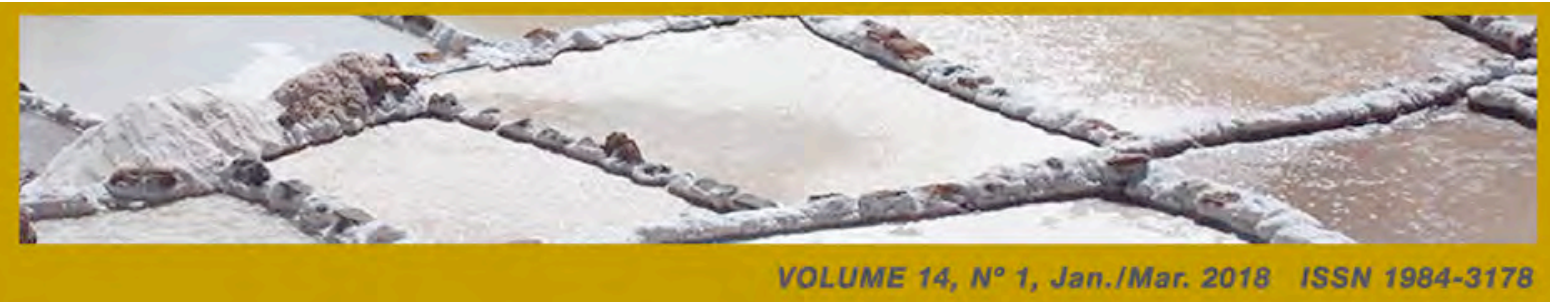

caçar. Cria ali surpresas. Consegue estar onde ninguém espera. É astúcia” (CERTEAU, 2013, p.95).

Trata-se, portanto, das vivências informais, e vivências em espaços não escolares, dos estudantes de Música do Bom Jardim que, mesmo sem o contato nas instituições escolares e distantes dos principais centros de ensino de música de Fortaleza, conseguiram desenvolver a prática musical. "As táticas [se contrapõem] às paisagens de poder, infiltrando-se na ordem urbana e criando fissuras que possibilitam vislumbrar as formas destoantes de uma vida cotidiana supostamente estável e regular" (LEITE, 2010, p.747).

O Centro Cultural e o Projeto dialogam com essas táticas ao introduzir ou ampliar a arte de fazer música no cotidiano dos estudantes. Esse espaço surge em seu dia-a-dia de maneiras diferentes. Dos dez estudantes, seis (André, Salatiel, Marlon, Beneildo, Eliana e Victor) conheceram o CCBJ a partir do curso de Prática de Conjunto. Os outros quatro estudantes (Mariana, Samila, Silvio e Leandro) conheceram por indicação de amigos que já estavam no curso ou através de outras atividades, como balé e jogos digitais. Além disso, a escola ao lado do CCBJ também é um espaço importante, dialogando muitas vezes com o Projeto e levando seus estudantes para atividades na instituição.

Apesar disso, as atividades do Projeto e mesmo do CCBJ ainda são pouco conhecidas pela comunidade do bairro. Uma das estudantes nos mostra a importância de divulgar o espaço e como compartilhava com os amigos as apresentações no Projeto Jardim de Gente:

[...] quando eu tinha tempo, eu procurava o projeto e aproveitava ao máximo um espaço desse aqui em frente à minha casa, eu não posso deixar de participar e também de divulgar. Não é só eu estando ali e usufruindo daquilo. Eu também divulgo muito os trabalhos daqui. Defendo também quando e onde eu posso, eu digo: "Ah... tem umas apresentações". Assisto às apresentações. Divulgo. Então, eu tô sempre falando porque eu to muito dentro do projeto e tal. Eu acho que um espaço como esse foi feito justamente pra comunidade. Então eu que sou da comunidade. Que moro aqui desde que eu nasci... eu tenho o direito de participar, mas também tenho o dever de tá divulgando, de tá fortalecendo, de tá contribuindo, de tá trazendo ideias (MARIANA). 


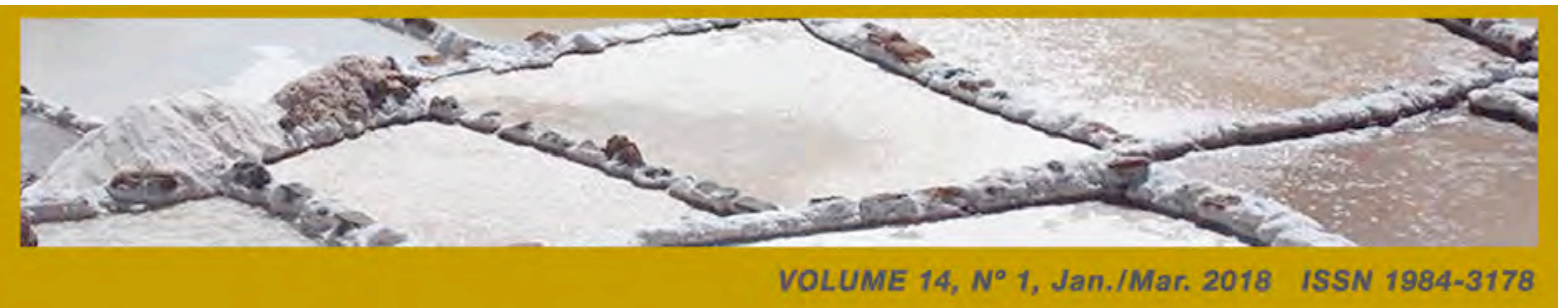

Além da dificuldade na divulgação do espaço em certos momentos, existe também a incerteza de retorno das atividades do Projeto após seu término, tornando inviável a formação continuada - tão importante dentro do contexto em que o Projeto está inserido. Uma estudante relata que:

[Em] 2013 [o projeto] ficou parado até junho, julho, aí não deu mais. Aí do meio pro fim do ano, eu tava muito ocupada. [Além disso,] "a Prática de Conjunto foi pra semana.... o Jardim de Gente... foi o tempo que parou e não voltou mais, aí, quando voltou, a prática tava na semana. Aí não dava pra mim na semana, aí eu não fui mais também (SAMILA).

Apesar disso, existem alunos que conseguem se manter no curso. Victor explica alguns motivos que o incentivam a sempre se matricular na Prática de Conjunto:

Porque, cara, é como... tu aprende uma coisa, mas não consegue se desgrudar daquilo. Virou um hobby também. Abrir Prática de 2015 eu vou tá aí. A de 2016 também. Mesmo que não tenha mais nada pra... claro que tem coisas novas pra aprender, porque eu conheço os ritmos novos, porque eu conheço novos jeitos de criar música (VICTOR).

A permanência aqui surge como tática de cada estudante de acordo com seu objetivo maior dentro da Música. Dos dez estudantes, alguns adentraram profundamente no mundo musical, seja no nível prático ou no nível acadêmico. Alguns já tinham intenção profissional antes do curso e, após início das atividades no Projeto, o desejo inicial se fortaleceu. Outros visualizaram o curso apenas por lazer, hobby, mas utilizam os conhecimentos adquiridos em suas práticas cotidianas. Existem ainda aqueles que tiveram sua percepção modificada pela prática musical no decorrer do curso e passaram a perceber a Música como uma possibilidade de futuro profissional e ascensão social.

O estudante Salatiel aponta seu objetivo ao ingressar no curso quando afirma que “desde o começo sempre foi assim... o gosto de tocar com... de tocar mesmo... de tocar... e... pensar em talvez... tipo, montar uma banda e sair por aí tocando profissionalmente. Daí a necessidade de procurar o curso" (SALATIEL). 


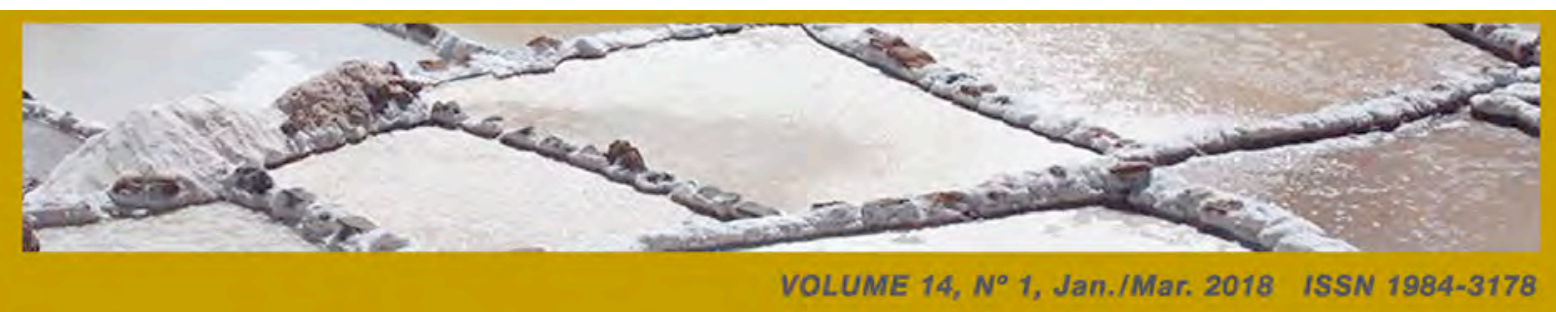

Apesar da intenção inicial com o trabalho no meio musical, Salatiel explicita um pouco sobre as dificuldades que encontrou no percurso ${ }^{12}$ :

Um ponto muito importante que eu tava inclusive conversando com meu professor de Violão... é... a questão de você viver daquilo que você gosta, né? Daquilo que é seu sonho desde novo. Por exemplo, eu entrei na prática já pensando em viver profissionalmente disso. E isso com certeza foi um alicerce muito bom pra eu estar hoje no curso Técnico de Instrumento Musical no IFCE, e isso me preparou bastante. Ou seja, eu já cheguei aqui com alguma bagagem, com algum conhecimento e tô só somando agora. Com relação a viver disso, é um escape pra mim assim... porque muitos estudantes de música tem que sair dali... daquele... às vezes, tem uma evasão muito grande nos cursos de música por isso, porque eles precisam trabalhar, porque o curso de Música... o músico ele não é muito valorizado... falta muito disso, sabe? A profissão de músico é visto como algo que ... enfim, existe muito preconceito em torno disso ainda. Aqui e em outras cidades. Existe muito disso. De você ser músico e ainda ter que trabalhar em algum emprego formal. Comigo também foi dessa maneira, certo? Eu fui exposto a diversos fatores que me atrapalham hoje na Música, por conta de que eu precisava trabalhar de que... enfim. Por exemplo, eu tenho uma lesão no meu braço que foi algo que foi causado por um emprego formal e tal... tem fatores psicológicos também que influenciam. A questão de estresse, dependendo do trabalho que você tá. Daquela frustração de você querer trabalhar em uma área e não conseguir... então... falta mais oportunidade pros músicos. Falta mais investimento nessa parte, eu acho. De dar oportunidades (SALATIEL).

Três dos estudantes entrevistados (Salatiel, André e Mariana) corroboram com a ideia do Projeto e do curso de Prática de Conjunto como importantes caminhos para a prática musical dentro do Grande Bom Jardim:

Os cursos oferecidos pelo Jardim de Gente, principalmente no meu caso, a questão da Música, são extremamente importantes. Principalmente pra mudar a realidade de muitos jovens lá, porque é um bairro que ele tem índices muito negativos com relação a educação, violência e enfim... vários outros aspectos. E a questão da cultura dentro de uma comunidade assim, com esses dados, com essas características, ajuda pra caramba a mudar, sabe?! Ajuda pra caramba as crianças e os jovens terem outros caminhos pra seguir, outras ocupações. Porque o tempo que eles não tão no colégio ou num curso desse, por exemplo, eles estão sujeitos a diversas outras coisas, né? Como a questão

\footnotetext{
${ }^{12} \mathrm{O}$ estudante Salatiel terminou o curso Técnico de Instrumento Musical (Violão) do Instituto Federal de Ciência e Tecnologia do Ceará (IFCE), tem dois projetos autorais e pretende ingressar no curso de Graduação em Música.
} 


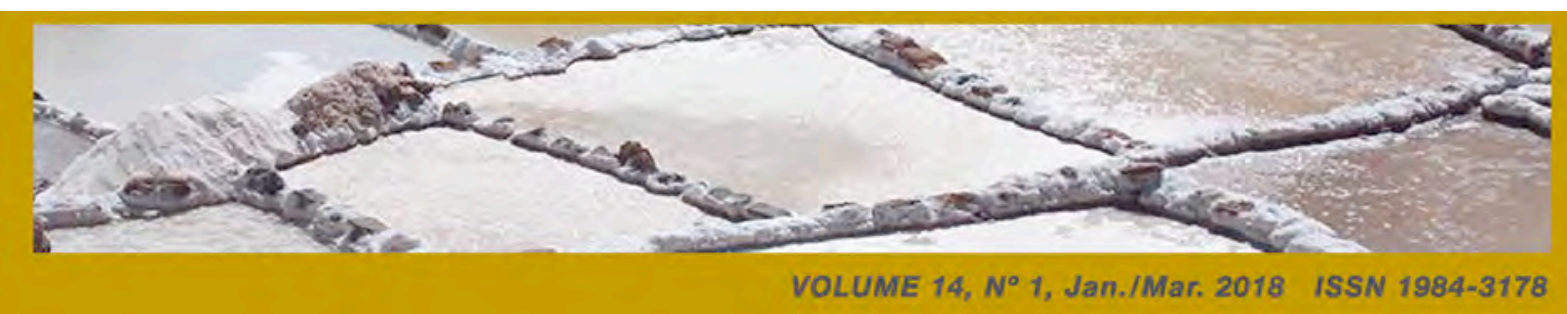

da violência, da marginalização, que eles sofrem muito. Isso ajuda a mudar o ponto de vista deles. A perspectiva de futuro. Então, eles mudam tanto o comportamento deles, como justamente esses novos caminhos pra seguir. Ajuda a formar pessoas. O curso de Música ajuda muito nisso. A questão da disciplina, a questão de horário, que são coisas básicas, mas que vão sendo levadas para o resto da vida. A responsabilidade de ter algo pra produzir, chegar em casa: "Ah, eu vou ouvir essa Música, eu vou pensar nisso pra levar como ideia, então já vai gerando uma responsabilidade, já vai gerando uma outra forma de vida. A questão do bem estar, a convivência com a família. Acho que isso muda muito também. Isso muda muito... porque a maioria dos jovens nessa região lá, no caso do Bom Jardim, tem um incentivo muito grande pras práticas ilícitas e, dentro do curso de Música, isso já é mais banido. As ideias são diferentes. Geralmente, as pessoas que procuram a música já tem um pensamento diferente e, quando você não tem muito essa noção, esse pensamento parecido com eles, quando você entra nesse meio, você pega um pouco de cada um e aí você muda completamente. [...] E também pela oportunidade, porque estudar é algo que não é... nem todo mundo tem condições de estudar música. Nem tempo, porque muitas crianças às vezes precisam trabalhar muito jovens, sei lá... a partir de 15 anos ou até mais cedo, já começa a trabalhar pra ter que ter um sustento pra casa ou pra si mesmo... enfim, e aí acaba que, quanto mais oportunidades pros jovens de questão de estudo, pros pais dos jovens porque tem também a questão da estrutura familiar, pra que eles possam ter acesso a esse tipo de cultura, a esses equipamentos (SALATIEL).

Além disso, "o projeto faz com que as pessoas que vivem nas suas casas, que têm sua vida diária de afazeres, saiam [...] para presenciar a apresentação de cursos, a linguagem das pessoas que vieram para fazer o curso e até ouvir essas pessoas" (ANDRÉ).

Assim, o curso se estabelece como importante espaço para a formação musical e responsável pela mudança de perspectivas com relação à prática musical dentro do Grande Bom Jardim.

A estudante Mariana ${ }^{13}$ também aponta aspectos relevantes sobre o curso:

[...] prática de conjunto é isso. Você se juntar com uma galera que toca e toca e tal e formar. Então, a partir do curso em si, ele já te dá uma bagagem pra você querer ir além. Não ficar só ali. Não só ficar se matriculando e sempre aluno do Centro Cultural para sempre. (Risos) Acho que tem realmente essa questão de sair. De continuar. De formar banda e tal (MARIANA).

\footnotetext{
${ }^{13}$ Mariana atualmente está com um grupo que iniciou na Prática de Conjunto em 2009 (os outros integrantes foram entrevistados também), tendo feito um show recente no Centro Dragão do Mar de Arte e Cultura (com cachê) e marcando outros shows para as temporadas de 2016.
} 


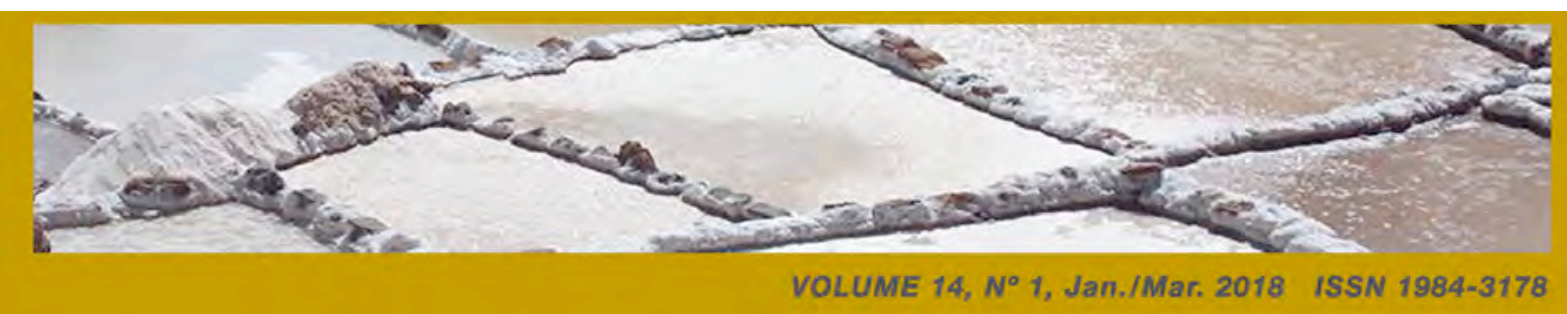

O estudante Silvio ${ }^{14}$ nos mostra em seu relato como o curso reinventou seu cotidiano, incentivando-o a dar continuidade às experiências musicais:

Cara... a importância do curso pra comunidade é muito grande. Porque dentro do Bom Jardim, do Grande Bom Jardim, tem pessoas que tocam divinamente bem que... tem uma desenvoltura musical muito grande mas... assim... não tem aquele incentivo musical pra crescer mais e mais. E o projeto é mais voltado pra isso. Pra desenvolver isso e apoiar aquelas pessoas que não tem tanto apoio. Que não tem aquela oportunidade de entrar em uma faculdade de música, que não tem aquela disponibilidade de fazer um curso profissionalizante mais... que seja pago então, tudo isso influencia o curso de Prática de Conjunto e leva a pessoa a ter uma visão diferente da música. E pra mim, foi a partir da prática de conjunto que eu comecei a ver a música como algo pra minha vida. Que eu quero ter pra toda a minha vida. Que eu quero trabalhar com isso, que eu quero viver disso. Então foi a partir do curso de prática de conjunto que eu comecei a ter esse pensamento. Então mudou muito a minha cabeça nesse ponto de vista (SILVIO).

Outros dois estudantes (Marlon e Victor ${ }^{15}$ ) apontam o curso e o Projeto como fundamentais para a escolha do futuro profissional. Um deles, Marlon, foi o único até o momento que ingressou na Licenciatura em Música da UFC. Ele afirma em seu relato as dúvidas na escolha do curso de graduação:

Assim... é... na verdade assim... uma também foi uma grande... foi uma
grande confusão também porque eu tinha afinidade por Arquitetura. Gostava
e era o que eu queria fazer. Isso era o que a minha família apoiava. Eu
treinava vôlei. Jogava já no Náutico e tal... tava tudo caminhando bem
também, e, ao mesmo tempo, eu aprendia os instrumentos. Então, quando eu
cheguei no terceiro ano, eu tive que fazer uma escolha dos três. E aí... foi ai
que o bicho pegou fogo, porque a Arquitetura eu realmente deixei de gostar,
assim... tanto do que eu gostava antes. Ai ficou entre dois: O esporte ou a
música. O esporte eu sabia que conseguiria, com mais trabalho, mas daria

${ }^{14}$ Silvio participou do curso durante dois anos e atualmente tem se dedicado à Orquestra Escola e Orquestra Sinfônica da UFC, como violista, e pretende ingressar no curso superior de Música. Além disso, tem um grupo musical evangélico.

${ }^{15}$ Victor, apesar de descrever seu interesse pelo curso apenas como hobby, e mesmo tendo sua vida acadêmica em outra área, possui muitas práticas musicais profissionais. Além de dois grupos que sempre têm shows marcados, constantemente é convidado por um amigo que conheceu na Prática para shows esporádicos (freelancer) com seu grupo de Pagode. Foi a partir do curso de Prática de Conjunto que Victor iniciou todas essas atividades: através da vivência com outros estudantes de música e da prática em grupo. 
certo também só que pra questão de faculdade e aí também teve participação essencial do Bruno ${ }^{16}$ por que eu tive uma conversa com ele uma vez e tal e ele falou assim: "Macho, se for por dinheiro ou por apoio, não vai nessa, não, porque daqui a um tempo tu vai ver que a escolha não era a certa." Aí eu... pensei, pensei, pensei, aí eu: Ah, vou colocar pra Música. Passei, consegui passar na UFC e tal (MARLON).

Nessa perspectiva, podemos compreender o Projeto, principalmente na área da Música, foco da pesquisa, como um espaço de mudança de realidades e perspectivas, de táticas, um espaço de reinvenção do cotidiano, de incentivador da arte de fazer Música.

\section{CONSIDERAÇÕES FINAIS}

Para compreender a importância do Projeto Jardim de Gente para a comunidade do Grande Bom Jardim, conhecemos as histórias de seus frequentadores analisando desde sua formação musical inicial até as vivências no Projeto. Além disso, conhecemos as propostas e objetivos formativos tanto do espaço dessa pesquisa como também do curso de Prática de Conjunto, a fim de dialogar com os relatos dos estudantes.

Nessa perspectiva, a pesquisa nos direcionou para a reflexão da prática musical sob a perspectiva dos "consumidores". Assim, temos em Koellreutter (1997) um importante referencial para a formação musical na instituição e em Bourdieu (1998; 2013) e Certeau (2013) um referencial que dialogasse com a realidade dos estudantes entrevistados.

As histórias, vivências e reflexões presentes nessa pesquisa nos apresentam práticas musicais exitosas na periferia de Fortaleza. A partir dos resultados, confirma-se a hipótese inicial que consistia em o Projeto Jardim de Gente ser um motivador de mudanças de perspectivas - nesse caso específico, da prática musical nos frequentadores dos cursos de Música do CCBJ.

Essas mudanças estão aliadas a propostas maiores, como um curso de Música a nível superior sem o tradicional Teste de Habilidade Específica (como é o caso da UFC), que oportuniza a entrada de estudantes de diversas regiões da cidade, e também as cotas

\footnotetext{
${ }^{16}$ Professor do curso de Prática de Conjunto em 2012 e 2013.
} 


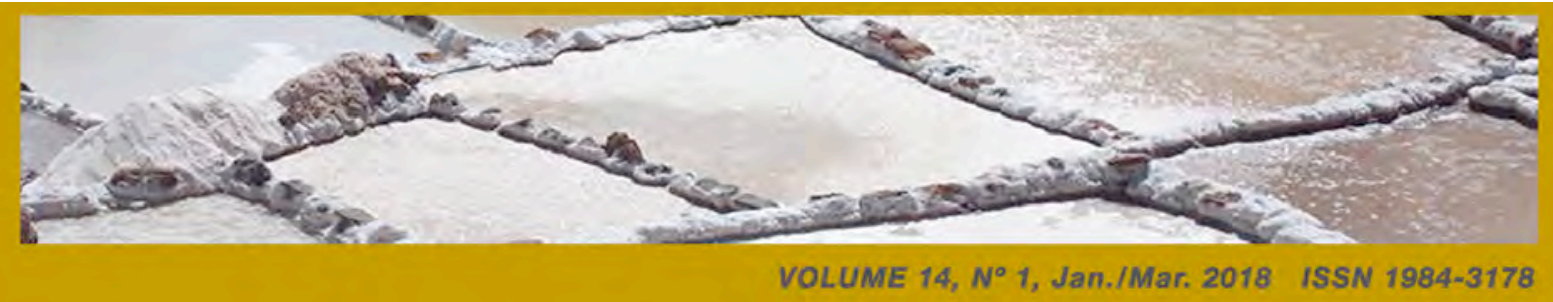

nos Institutos e Universidades Federais, implementadas em 2012. Tais modificações ampliam as possibilidades de acesso ao saber musical mais sistematizado, até então bastante restrito em Fortaleza.

Além disso, a pesquisa mostra, a partir dos relatos dos estudantes, pontos importantes que devem ser repensados no Projeto e no curso. Assim, o espaço pode evoluir e continuar oportunizando mudanças significativas nas práticas da comunidade do Grande Bom Jardim.

Ao ser questionado novamente acerca da influência do Projeto Jardim de Gente na formação musical de seus estudantes e qual sua importância na formação dos seus frequentadores, a resposta fica evidente: o projeto é responsável por mudanças significativas na vida dos estudantes, além da comunidade de uma maneira geral.

Indo mais além, a influência não é apenas musical, mas também dialoga com outros aspectos que não eram evidentes apenas com a observação das aulas enquanto professor. Percebemos assim, que a formação direcionada pelo curso torna os estudantes mais questionadores e ativos em sua vida cotidiana. Mesmo que de maneira não intencional e, apesar de todas as dificuldades e limitações burocráticas e políticas, o Projeto torna-se o principal espaço de aprendizagem musical do Grande Bom Jardim.

A pesquisa nos mostra, a partir de seus protagonistas, que o bairro Bom Jardim não deixa de produzir por estar à margem das práticas centrais da cidade. Ao contrário, ele cria táticas e torna-se ativo como produtor de alternativas quando incentivado a isso.

Espera-se que este trabalho incentive outros estudos tendo em vista a necessidade de se compreender mais sobre os espaços de formação nas periferias das cidades e sua função nas comunidades onde estão inseridos, a exemplo do que vem acontecendo com a pesquisa intitulada: "Estudo sobre as práticas musicais em espaços não institucionalizados no Canadá e no Brasil: formação humana e desenvolvimento através da Educação Musical em comunidades de situação de vulnerabilidade social”. Essa pesquisa possui apoio da Coordenação de Aperfeiçoamento de Pessoal de Nível Superior (CAPES), da Fundação de Apoio ao Desenvolvimento Científico e Tecnológico (FUNCAP) em parceria com a Universidade de Laval (Québec/Canadá) e a UFC (Fortaleza e Sobral) que surgiu a partir 


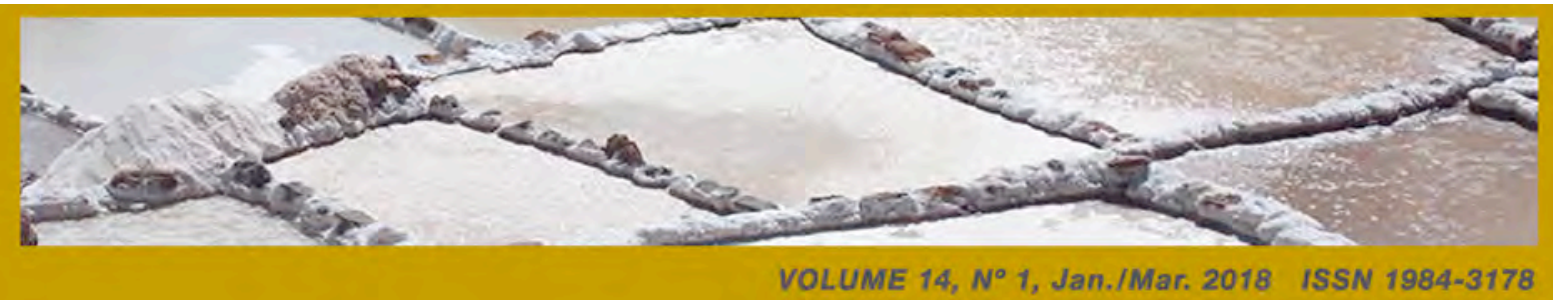

da análise das práticas musicais no Projeto Jardim de Gente/ Bairro Bom Jardim (FortalezaCeará).

\section{REFERÊNCIAS}

ALMEIDA, Maria Lucineide Freire de; FERREIRA, Miquéias Gomes; BARBOSA, Émerson da Silva; FERREIRA, Gabriel Nunes Lopes; NASCIMENTO, Marco Antonio Toledo. A Educação Musical em Três Escolas públicas do Ceará: panorama de uma realidade estadual. In: CONGRESSO NACIONAL DA ABEM, 22., 2015, Rio Grande do Norte, Anais... Natal, 2015. Disponível em:

$<$ https://goo.gl/nNtW27>. Acesso em: 06 jul. 2017.

ANADON, Marta. A pesquisa dita qualitativa: sua cultura e seus questionamentos. Comunicação apresentada no colóquio internacional Formação, pesquisa e desenvolvimento em Educação. Senhor do Bonfim: UNEB/UQAC, 2005.

BOURDIEU, Pierre. A escola conservadora: as desigualdades frente à escola e à cultura. Trad. Aparecida Joly Gouveia. In: NOGUEIRA, Maria Alice; CATANI, Afrânio (Org.). Pierre Bourdieu: escritos de educação. 2. ed. Petrópolis: Vozes, 1998. p. 39-64.

. Capital simbólico e classes sociais. Novos estudos, São Paulo, n. 96, p. 105-115, jul. 2013. Disponível em: <http://goo.gl/EuMqbq>. Acesso em: 10 ago. 2017.

BRITO, Teca Alencar de. Koellreutter educador: o humano como objetivo da educação musical. São Paulo: Editora Fundação Peirópolis, 2011.

CEARÁ. Lei Complementar $\mathrm{n}^{\circ} 37$, de 26 de novembro de 2003. Institui o Fundo Estadual de Combate à Pobreza - FECOP, nos termos da emenda constitucional federal $n^{\circ} 31$, de 14 de dezembro de 2000, cria o conselho consultivo de políticas de inclusão social, extingue os fundos que indica e dá outras providências. Diário Oficial [do Estado do Ceará], Fortaleza, CE, n.228, 27 nov. 2003, p.01.

CERTEAU, Michel de. A invenção do cotidiano: Artes de Fazer. Petrópolis: Vozes, 2013.

CRESWELL, J. W. Projeto de pesquisa: métodos qualitativo, quantitativo e misto. 3. ed. Porto Alegre: Artmed, 2010.

ECKERT, André Luis; LOURO, Ana Lúcia. Refletindo sobre a prática como professor de violão em um projeto social. In: CONGRESSO NACIONAL DA ABEM, 19., 2010, Goiânia, Anais... Goiânia, 2010, p. 2408-2413. Disponível em: < https://goo.gl/f991Cb>. Acesso em: 18 jun. 2017.

FERREIRA, Gabriel Nunes Lopes. Ensino Coletivo de violão na periferia de fortaleza: um relato de experiências. In: ENCONTRO NACIONAL DE ENSINO COLETIVO DE INSTRUMENTOS MUSICAIS, 6., 2014, Salvador, Anais... Salvador, 2014. p. 359-368. Disponível em: $<$ https://goo.gl/RCnrqI $>$. Acesso em: 13 ago. 2017. 


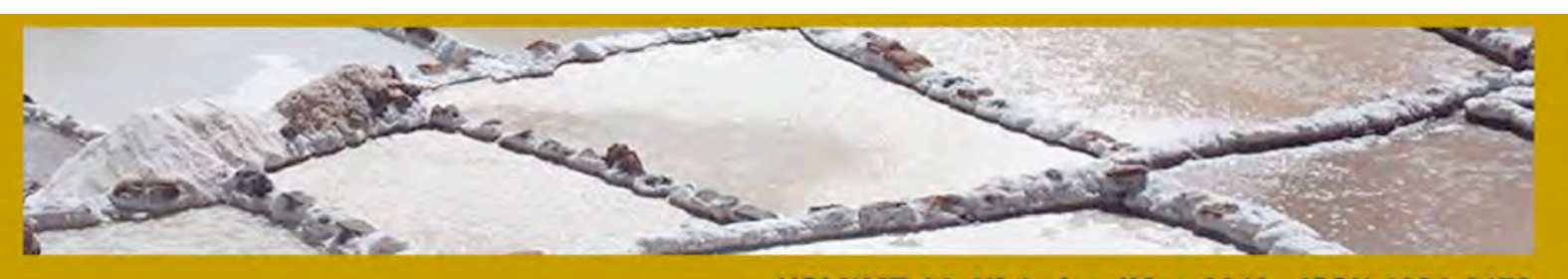

FUCCI AMATO, Rita de Cássia. Capital cultural versus dom inato: questionando sociologicamente a trajetória musical de compositores e intérpretes brasileiros. Opus, Goiânia, v. 14, n. 1, p. 79-97, jun. 2008. Disponível em: <http://goo.gl/ZbK8Lc>. Acesso em: 25 jul. 2017.

. Canto coral e inclusão social: um panorama atual de iniciativas brasileiras. In: CONGRESSO NACIONAL DA ABEM, 18., 2009, Londrina, Anais... Londrina, 2009. p. 379-385. Disponível em: < https://goo.gl/XBWe4R>. Acesso em: 17 jun. 2017.

GAULKE, Tamar Genz; LOURO, Ana Lúcia de Marques e. Adaptando e reconstruindo ideias: dilemas no ensino de violino em um projeto social. In: CONGRESSO DA ANPPOM, 20., Florianópolis, Anais... Florianópolis, 2010. p. 481-485. Disponível em: <http://goo.gl/usKPe6>. Acesso em: 17 ago. 2017.

GLASER, B. G.; STRAUSS, A. L. The Discovery of Grouded Theory: Strategies for Qualitative Research. New York: Aldine, 1967.

HELLER, A. O cotidiano e a história. 8. ed. São Paulo: Paz e Terra, 2008.

HIKIJI, Rose Satiko Gitirana. A música e o risco. São Paulo: Edusp, 2006.

HONÓRIO, Raquel Santos. A Cultura como estratégia de combate à pobreza: a experiência do Projeto Jardim de Gente no Centro Cultural Bom Jardim. Dissertação (Mestrado profissional em Planejamento e Políticas Públicas). Universidade Estadual do Ceará, Fortaleza, 2014.

KLEBER, Magali Oliveira.; CACIONE, Cleusa Erilene Santos.; ERTHAL, Júlio César Silva. Educação Musical e Movimentos Sociais. In: CONGRESSO NACIONAL DA ABEM, 19., 2010, Goiânia, Anais... Goiânia, 2010, p. 745-755. Disponível em: < https://goo.gl/hSArz8>. Acesso em: 18 ago. 2017.

KLEBER, Magali Oliveira. Educação musical: novas ou outras abordagens - novos ou outros protagonistas. Revista da ABEM, Porto Alegre, n. 14, p. 91-98, mar. 2006.

A rede de sociabilidade em projetos sociais e processo pedagógico musical. In: CONGRESSO NACIONAL DA ABEM, 19., 2010, Goiânia, Anais... Goiânia, 2010, p. 363-373. Disponível em: < https://goo.gl/hSArz8>. Acesso em: 18 ago. 2017.

A prática de educação musical em ONGs: dois estudos de caso no contexto urbano brasileiro. Curitiba: Appris, 2014.

KOELLREUTTER, H.J. Sobre o valor e o desvalor da obra musical. In: Kater, Carlos (Org.) Cadernos de estudo: educação musical. Belo Horizonte: Atravez/EMUFMG/FEA/FAPEMIG, ${ }^{\circ}$ 6, 1997.

LEITE, Rogério Proença. A inversão do cotidiano: práticas sociais e rupturas na vida urbana contemporânea. Revista de Ciências Sociais, Rio de Janeiro, v. 53, n. 3, p. 737-756, 2010. Disponível em: <http://goo.gl/CS1BRe>. Acesso em: 21 jul. 2017.

MACIEL, Edineiram Marinho. Música em projetos sociais: caminho para inclusão? In: CONGRESSO NACIONAL DA ABEM, 19., 2010, Goiânia, Anais... Goiânia, 2010, p. 1298-1306. Disponível em: < https://goo.gl/hSArz8>. Acesso em: 18 ago. 2017. 


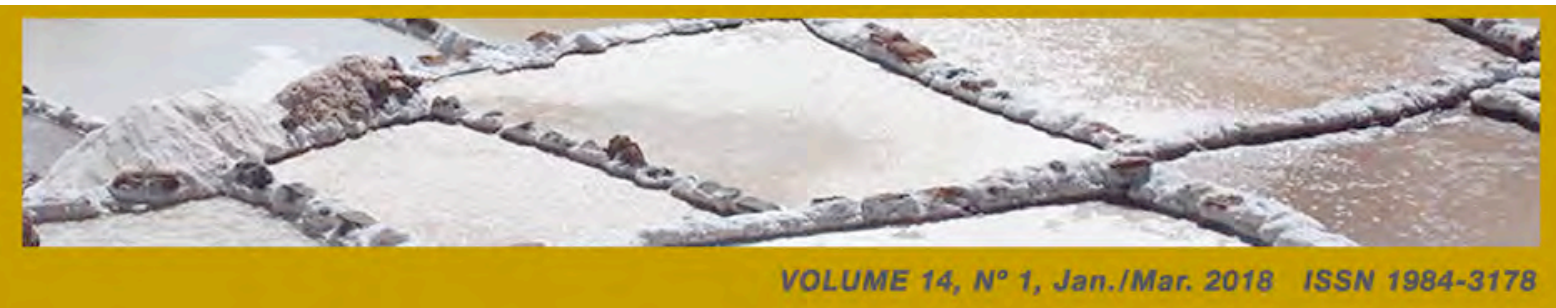

OLIVEIRA, Thiago Fonseca. Oficina de música no Programa de Controle de Homicídios Fica Vivo: o ensino de música a serviço da defesa social. In: CONGRESSO NACIONAL DA ABEM, 19., 2010, Goiânia, Anais... Goiânia, 2010, p. 1709-1718. Disponível em: < https://goo.gl/f991Cb>. Acesso em: 18 jul. 2017.

OBA, Cheila Marie Felippin; LOURO, Ana Lúcia. Práticas educativas no contexto do projeto social: dilemas, reflexões e contribuições para a formação de uma licencianda em música. In: CONGRESSO NACIONAL DA ABEM, 19., 2010, Goiânia, Anais... Goiânia, 2010, p.1855-1863. Disponível em:

$<$ https://goo.gl/f991Cb>. Acesso em: 18 jul. 2017.

PENNA, Maura; BARROS, Olga Renalli Nascimento; MELLO, Marcel Ramalho. Educação musical com função social: qualquer prática vale? Revista da ABEM, Porto Alegre, v. 27, p. 6578, jan./jun. 2012. Disponível em: < http://goo.gl/lddjX9>. Acesso em: 5 jul. 2017.

ROBATTO, Lucas. Por que música na escola? In: JORDÃO, Gisele; ALLUCCI, Renata R.; MOLINA, Sergio; TERAHATA, Adriana Miritello. (Coord.). A música na escola. São Paulo: 3D3 Comunicação e cultura: Allucci e Associados Comunicações, 2012. p. 49-51. Disponível em: < https://goo.gl/eCMzhw>. Acesso em: 12 ago. 2017.

STRAUSS, A. L.; CORBIN, J. Basics of qualitative research. London: Sage,1990.

STRAVACAS, Isa. Educação Musical em espaços não formais de Ensino. In.: VERCELLI, Ligia A. (Org.). Educação não formal: Campos de Atuação; Jundiaí: Paco editorial, 2013. p. 61-85.

WEILAND, Renate Lizana. Relações entre projetos comunitários e música na perspectiva de profissionais da área musical em Curitiba: algumas contribuições da psicologia social comunitária e da educação. Tese (Doutorado em Educação). Universidade Federal do Paraná, Curitiba, 2010.

WEILAND, Renate Lizana; FERMINO, Lucas. Música em projetos sociais: educação musical para crianças na periferia de um centro urbano - integrando diferentes instituições com vistas a uma participação conjunta. In: CONGRESSO INTERNACIONAL DE EDUCAÇÃO, PESQUISA E GESTÃO, 4., 2012, Paraná, Anais... Paraná, 2012. Disponível em: <http://goo.gl/oYVB90>. Acesso em: 19 ago. 2017.

YIN, Robert K. Estudo de caso: planejamento e métodos. 4. ed. Porto Alegre: Bookman, 2010.

Recebido em 25 de agosto de 2017 Aprovado em 28 de dezembro de 2017 